\title{
Praktická implementace virtuálních návodek
}

\author{
Jan Kubr ${ }^{1}$, Konstantin Novikov ${ }^{1}$, Petr Hořejší ${ }^{1}$, Jana Kleinová ${ }^{1}$ \\ 1 Západočeská univerzita v PIzni, Fakulta strojní, Katedra průmyslového inženýrství a \\ managementu \\ Univerzitní 2732/8, 30614 Plzeň, Česká republika \\ kubri@kpv.zcu.cz \\ novikov@kpv.zcu.cz \\ tucnak@kpv.zcu.cz \\ kleinova@kpv.zcu.cz
}

\begin{abstract}
Anotace: Pozitivní dopady využití virtuální reality v průmyslu byly již mnohokrát prokázány. Jak je to ale s reálným nasazením této moderní technologie v praxi? Tento článek se zabývá implementací virtuálních návodek na pracoviště ve velkosériové výrobě z oblasti automotive. Cílem je ukázat, že virtuální návodky jsou smysluplným nástrojem pro zaškolování pracovníků. Přesto je třeba myslet na specifika dané výroby a koncových uživatelů tak, aby došlo ke správnému nastavení systému podávání informací a bylo dosaženo požadovaného zefektivnění výroby.
\end{abstract}

\section{1 Úvod}

$\checkmark$ dnešní době, kdy je kladen velký důraz na rychlost a kvalitu provedení výrobků, dostává virtuální realita (VR) více a více možností, jak uplatnit svůj potenciál. Virtuální realita je nástroj, který dokáže enormně zkrátit čas zaučení nových zaměstnanců, a to i méně kvalifikovaných, téměř odstranit chybovost a samozřejmě zvýšit produktivitu. Zatím je VR využívána ve velkých podnicích, kde se vyrábí nebo montují složitější výrobky a je kladen důraz na rychlost i přesnost výroby. Virtuální návodky nejsou souvislý film nebo sekvence obrázků, ale práce $v$ reálném čase, ve které se obraz mění podle následujících kroků dělníka, který postupuje podle pokynů návodky. Virtuální návodka může být promítána i přímo během výroby a přizpůsobena výrobnímu taktu. $V$ době, kdy je trh přesycený, je důležité, aby si společnosti udržely konkurenceschopnost. Virtuální návodky jsou silný nástroj pro zaškolování či hlídání kvality. Tato technologie se již stala jedním z moderních trendů nejen $v$ průmyslovém odvětví $a v$ blízké budoucnosti se může stát standardem pro každý podnik.

\section{Analýza}

V rámci pilotního projektu bylo vybráno pracoviště, kde probíhá výroba dílů pro přední automobilové značky, jakými jsou např́klad Audi nebo BMW. V závodu se vyrábí pohledové části karoserií, palubní desky, bezpečnostní výztuhy do dveří ale i nosníky některých prvků do motoru. Tyto nosníky se vyrábí bud' ocelové nebo hliníkové. Větší množství vyráběných kusů je 
z hliníku i díky své nižší hmotnosti, což pozitivně napomáhá k redukci emisí CO2. Částí provozovny, na které byla praktická část této práce realizována je, pracoviště Lisování matic. Toto pracoviště je rozdělené na dvě podskupiny a to: Zakládání dílů a Kontrola nalisování. Každé z těchto pracovišt' je obsluhováno jiným pracovníkem a každý z nich vykonává jiný druh pracovní náplně. Hlavní částí tohoto pracovního prostoru je lisovačka matic, do které se zakládá díl a na druhé straně pracoviště odebírá.

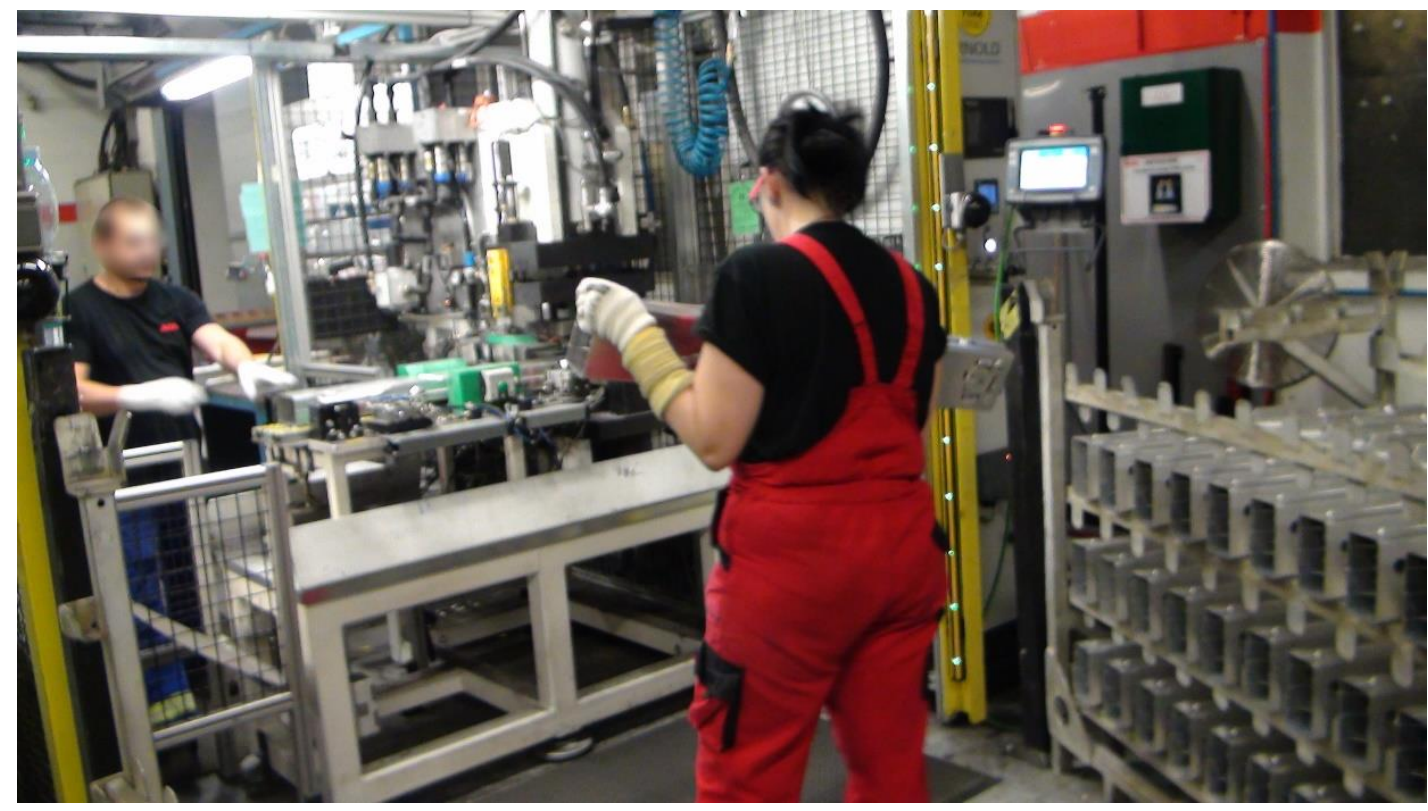

Obrázek 1 - Ukázka pracoviště Lisování matek [zdroj: autor]

Pro zpracování návodek bylo vybráno pracoviště Lisování matek samotným podnikem z důvodů vysoké chybovosti a pomalého zaškolování nového personálu. Pro vytvoření a samotnou realizaci výsledné návodky je zapotřebí provést několik analýz, které budou popsány $v$ kapitolách níže. Tyto analýzy napomohou k pochopení celého procesu a popíšou jednotlivé položky, které jsou zapotřebí pro tvorbu daných návodek.

Vycházet se bude $z$ metodiky navržené $v$ [1], přičemž tato metodika byla otestována na reálných projektech v různých typech výroby.

\subsection{Procesní analýza}

Cílem procesní analýzy bylo poznat a zmapovat současný stav celého procesu. Zjistit pracovní postup na jednotlivých pracovištích a dále s nimi pracovat. Toto pracoviště funguje na třísměnný provoz, prričemž každý pracovník má právo na 3 × 10 min pauzu a 1 × 30 min pauzu na oběd. Mimo tyto pauzy a jiné nepředvídatelné pauzy (rozbití stroje, zdržení dodávky materiálu z předchozího pracoviště) pracuje pracoviště nepřetržitě. Pro procesní analýzu bylo pracoviště Lisování matek rozděleno na dvě části:

- Založení do matkovačky

- Kontrola a odebrání z matkovačky 


\section{Založení do matkovačky}

Pracovním postupem této části procesu je:

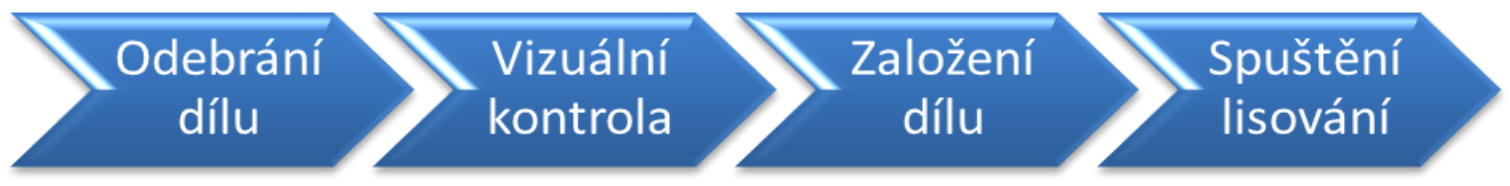

1. Odebrání dílu

Hliníkový díl se odebírá ze stojanů, které pro pracoviště připravuje manipulátor. Ten zajišt'uje nepřetržitý přísun materiálu na pracoviště. Díly je možné odebírat ze dvou stojanů - pravý/ levý. To zaručuje plynulý chod stroje. V každém stojanu je umístěno 48 dílu ve 4 patrech.

2. Vizuální kontrola

Po odebrání dílu ze stojanu je důležité díl vizuálně zkontrolovat na rizikových místech. Těmi jsou především svary. Tyto svary se nachází ze všech čtyř stran, proto je nutné s dílem rotovat tak, aby bylo možné nahlédnout na všechny strany.

\section{Založení dílu}

Zkontrolovaný díl je potřeba založit do přípravku v samotném lisovacím stroji. Pro správné vložení jsou na lisovacím stroji umístěny speciální prvky, které vyznačují, do jakých míst se má díl umístit. Ovšem je zapotřebí dbát zvýšené pozornosti na to, jakou stranou se díl do matkovačky vkládá. Po správném založení dílu na válečky následuje doražení dílu na speciální vystřed’ovací trn. Po doražení na trn je zapotřebí díl přitáhnout rukou směrem od středu ven $\mathrm{k}$ obsluze pro přisátí přitahovače dílu.

4. Spuštění lisování

Po správném zasazení dílu již následuje odstoupení od stroje a zmáčknutí tlačítka pro zadání signálu spuštění lisování. Odstoupení od stroje je i kvůli bezpečnosti sledováno světelnou bránou, která $v$ prípadě potřeby zamezí úrazu. Tlačítka pro spuštění se nacházejí na každé straně pracoviště pro obě varianty odebírání materiálu (pravá/levá). Zmáčknutí tlačítka je také signálem pro ukončení celého procesu na tomto pracovišti a obsluha začíná cyklus od začátku.

\section{Kontrola a odebrání z matkovačky}

Pracovním postupem této části je:

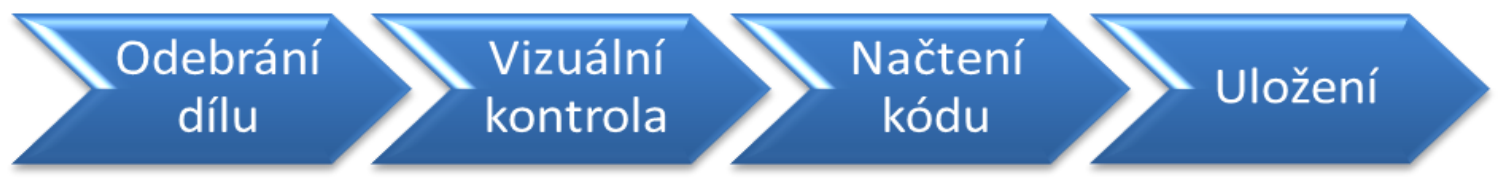

1. Odebrání dílu 
Po skončení samotného nalisování, které vykonává stroj, je zapotřebí díl odebrat z matkovačky. Pokynem pro odebrání je zobrazení zeleného světla na obrazovce nad vstupem do klece. Tato část procesu je kontrolována pomocí světelných bran, které jsou umístěny před vstupem do klece. $\checkmark$ prípadě vstoupení do zóny $v$ čas, který není určený $k$ odebrání dílu, se zobrazí červené světlo, zazní výstražný signál a stroj se zastaví.

2. Vizuální kontrola

Po odebrání je potřeba díl vizuálně zkontrolovat, a to především rizikové části, mezi které patří správné nalisování matek a kontrola propalů. Aby bylo možné tyto části zkontrolovat, je zapotřebí díl natočit a zkontrolovat $z$ více pohledů, aby bylo možné prípadnou vadu odhalit. $V$ prípadě nálezu vady na díle je možné tuto vadu odstranit přímo na pracovišti pomocí jednoduchých nástrojů (začištění pomocí kartáče) a nebo předat na opravu na pracoviště tomu prriřazené.

\section{Načtení kódu}

Následujícím krokem je natočení dílu pod speciální čtečku kódů nacházející se na stole vedle klece matkovačky. Načtení kódu z dílu slouží pro budoucí možné odhalení chyby ze série produktů. Díl se vloží pod čtečku a ta načte vyražený kód. Je zapotřebí dbát pozornosti na to, aby kód z dílu byl opravdu načten, a proto díl vkládat stranou s vyraženým kódem.

4. Uložení

Následujícím krokem je odebrání dílu od čtečky a jeho následné založení do připraveného boxu. Boxy jsou připraveny dva pro zajištění plynulého chodu celého procesu. $V$ každém boxu jsou pripraveny plastové prípravky, do kterých se díl ukládá. Díl je zapotřebí uložit správnou stranou. Do jednoho patra bedny se vejde sedm dílů, príčemž do jedné bedny jsou naskládána tři patra. Bedna je poté operátorem príikryta a odvezena do meziskladu, kde je připravena na expedici.

\section{2 Časová analýza}

Další důležitou částí celkové analýzy je analýza časová. $V$ této analýze byly využity definované činnosti jednotlivých kroků, které musí být vykonány pro dokončení procesu. Dále bylo zapotřebí tyto činnosti seřadit v kontinuální návaznosti. Pro celý tento proces bylo stanoveno 15 náměrů pro každou část pracoviště (Zakládání dílů/Kontrola dílů). Tato analýza poslouží k posouzení, s jakým taktem se na pracovišti pracuje a jaký typ návodky bude vhodný pro danou výrobu.

Časová analýza pracoviště: Zakládání dílů (čas udávaný v s) 


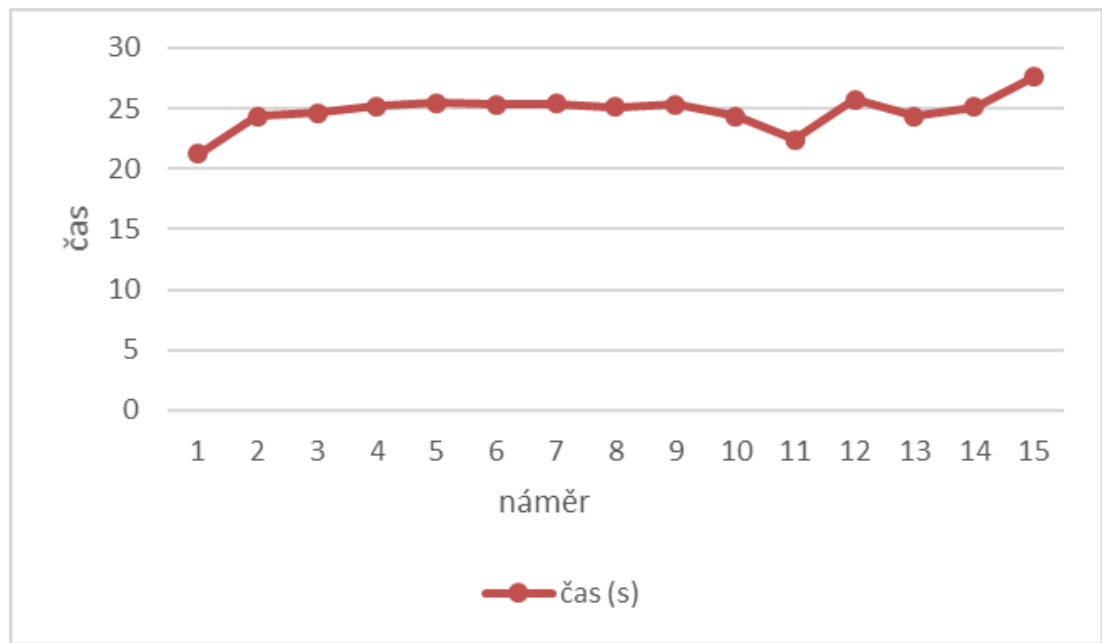

Obrázek 2 - Porovnání časů (zakládání dílů) [zdroj: autor]

Z výše uvedených náměrů vyplývá, že maximální takt pracoviště Zakládání dílů je zhruba $25 \mathrm{~s}$. Při tak vysokém taktu by nebylo možné stíhat mačkat další tlačítko a tím zdržovat pracovníka od daného výkonu, proto bylo nutné vytvořit návodku bez ovládání.

Časová analýza pracoviště: Kontrola dílů (čas udávaný v s)

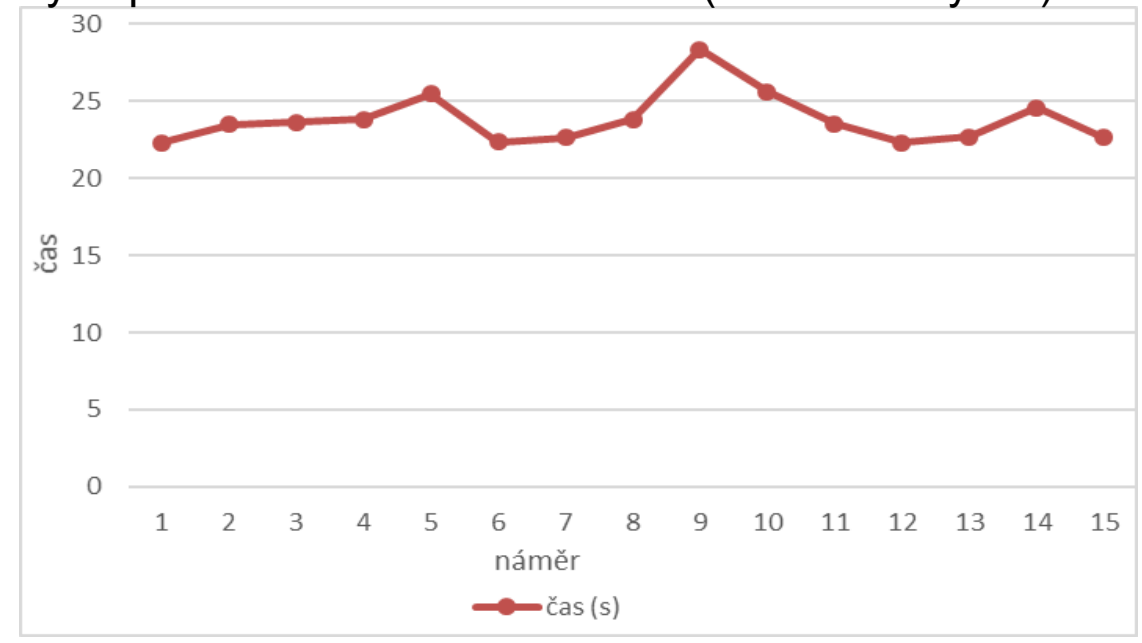

Obrázek 3 - Porovnání časů (kontrola dilì) [zdroj: autor]

Díky časové analýze bylo zjištěno, že na pracovišti kontroly se pracuje $v$ taktu nepřekračující $26 \mathrm{~s}$. Odchylka náměru 9 byla zpưsobena tím, že pracovník připravoval expediční box. Příprava boxu je tak jediným bodem v pracovním postupu, který by pro vylepšení procesu bylo dobré eliminovat. Z rychlosti taktu vyplývá, že nebude možnost zavést návodku spuštěnou přes tlačítko, protože by tato činnost zdržovala pracovníka.

\subsection{Datová analýza}

Aby mohla být samotná návodka vytvořena, je zapotřebí mít data, ze kterých může být tvořena. Pro tvorbu návodky $v$ Unity 3D jsou zapotřebí 3D modely. Od zadavatelů této práce byla poskytnuta CAD data pouze pro nosník motoru. Tato data ovšem byla zbytečně moc obsáhlá, a proto bylo zapotřebí zredukovat části, které se v návodce nevyužijí. Dalším problémem byl formát, 
ve kterém byl tento CAD model obdržen. Jednalo se o formát .CATPart. Tento typ modelu byl vytvořen prímo výrobcem v programu Catia V 5 od společnosti Dassault Systém. Pro úpravu modelu $v$ tomto programu byla využita učebna na Katedře konstruování strojủ na Fakultě strojní. V programu byly z modelu odebrány nadbytečné části, jakými byli např́ílad skici, prvky popisující jednotlivé komponenty modelu a především prvky, které nebyly pro další tvorbu návodky zapotřebí. Pro vložení modelu přímo do Unity 3D bylo zapotřebí tento model uložit $v$ jiném formátu. Nejlepší volbou pro takové uložení je formát .STEP, který je možné vložit např́ílad do programu 3DS Max. Tento krok je nutný z důvodu uložení do formátu .fbx, který je možno vložit a dále s ním pracovat prímo v Unity3D.

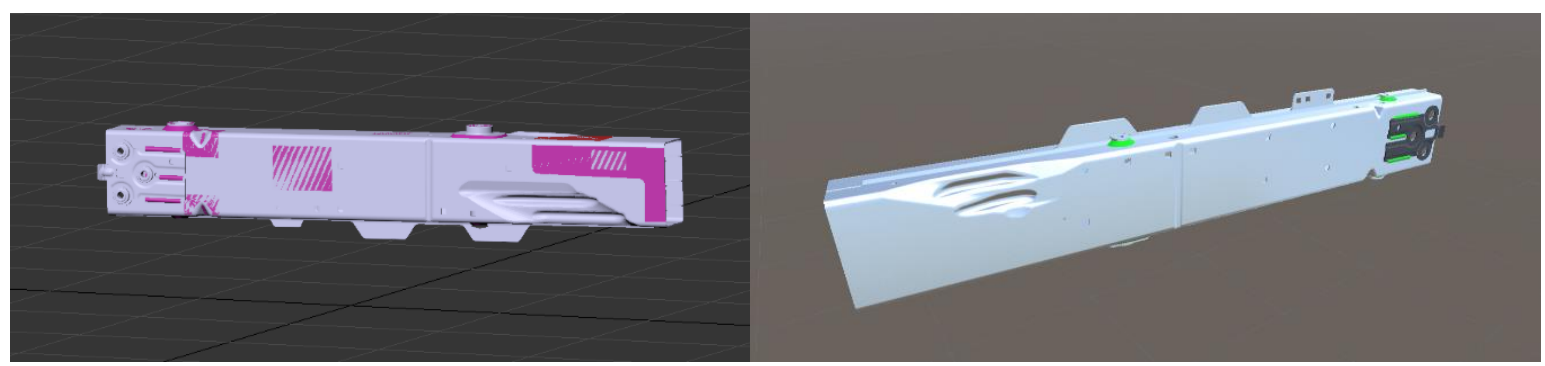

Obrázek 4 - Díl před/po úpravě [zdroj: autor]

Pro vytvoření kompletní návodky byl zapotřebí i model celého pracoviště. Protože tento model pracoviště nebylo zadavatelem poskytnut, bylo zapotřebí jej zpracovat $v$ modelovacím softwaru. Aby model odpovídal reálnému prostředí, bylo zapotřebí celé pracoviště zaměřit a detailně popsat. Velký důraz na přesnost a kvalitu byl kladen obzvláště na část pracoviště, kde se nachází samotné lisovací centrum matek. Stupeň kvality provedení této části ve velké míře napomáhá $\mathrm{k}$ lepší orientaci na pracovišti a ke správnému zacházení s komponenty. Pracoviště bylo vymodelováno v programu SolidWorks a základní materiály byly přidány v programu 3DS Max, ze kterého pak bylo možné jednotlivé prvky vkládat prímo do Unity 3D.

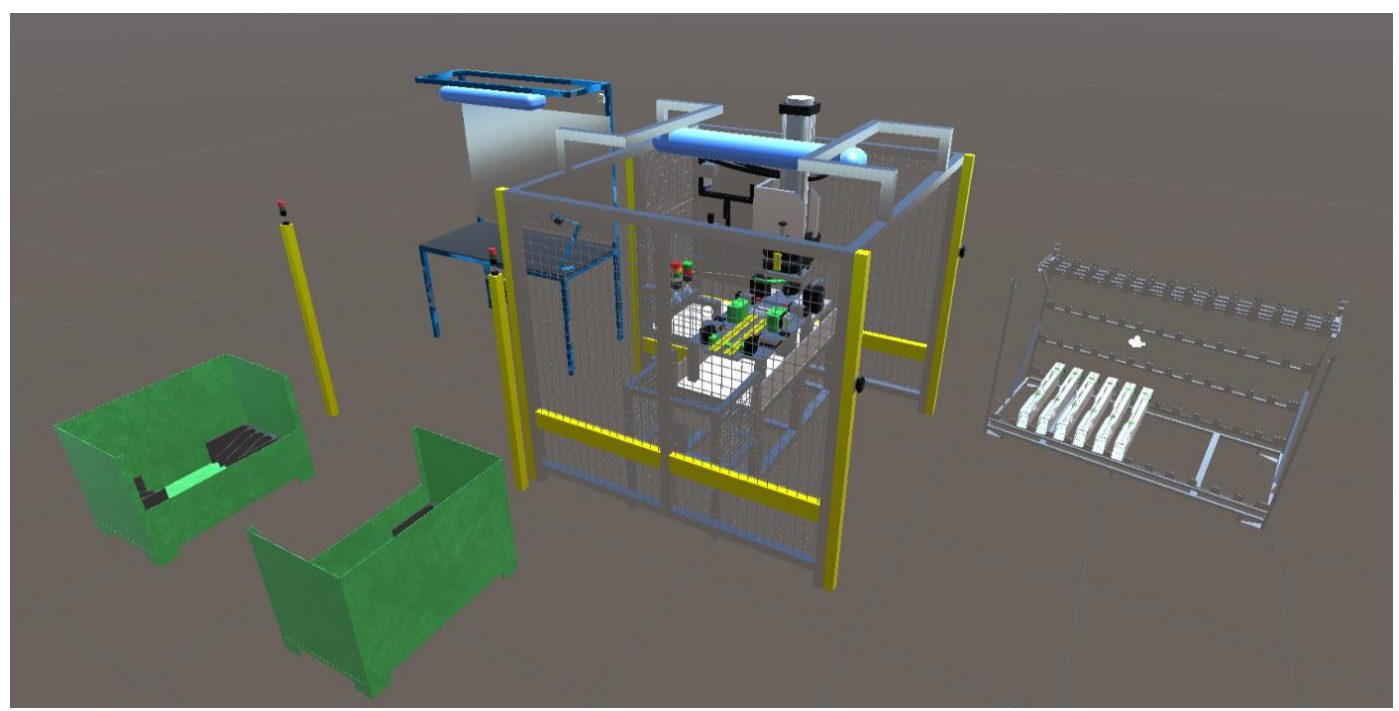

Obrázek 5 - Vytvořené pracoviště Lisování matek v Unity3D [zdroj: autor] 


\subsection{Prostorová analýza}

Prostorová analýza je důležitou součástí těchto analýz. Díky této analýze bylo zjištěno rozložení celého pracoviště, které je popsáno na obrázku. Dále byl zaznamenán pohyb jednotlivých pracovníků po pracovišti.

\section{Layout pracoviště}

Layoutem pracoviště se rozumí grafické znázornění rozložení pracoviště. Ukazuje na to, zda jsou výrobní prostory využívány efektivně, zda jsou výrobní kapacity podniku dostatečné nebo zda by tento výrobní systém byl schopen zvládnout navýšení objemu výroby nebo změnu výrobního programu.

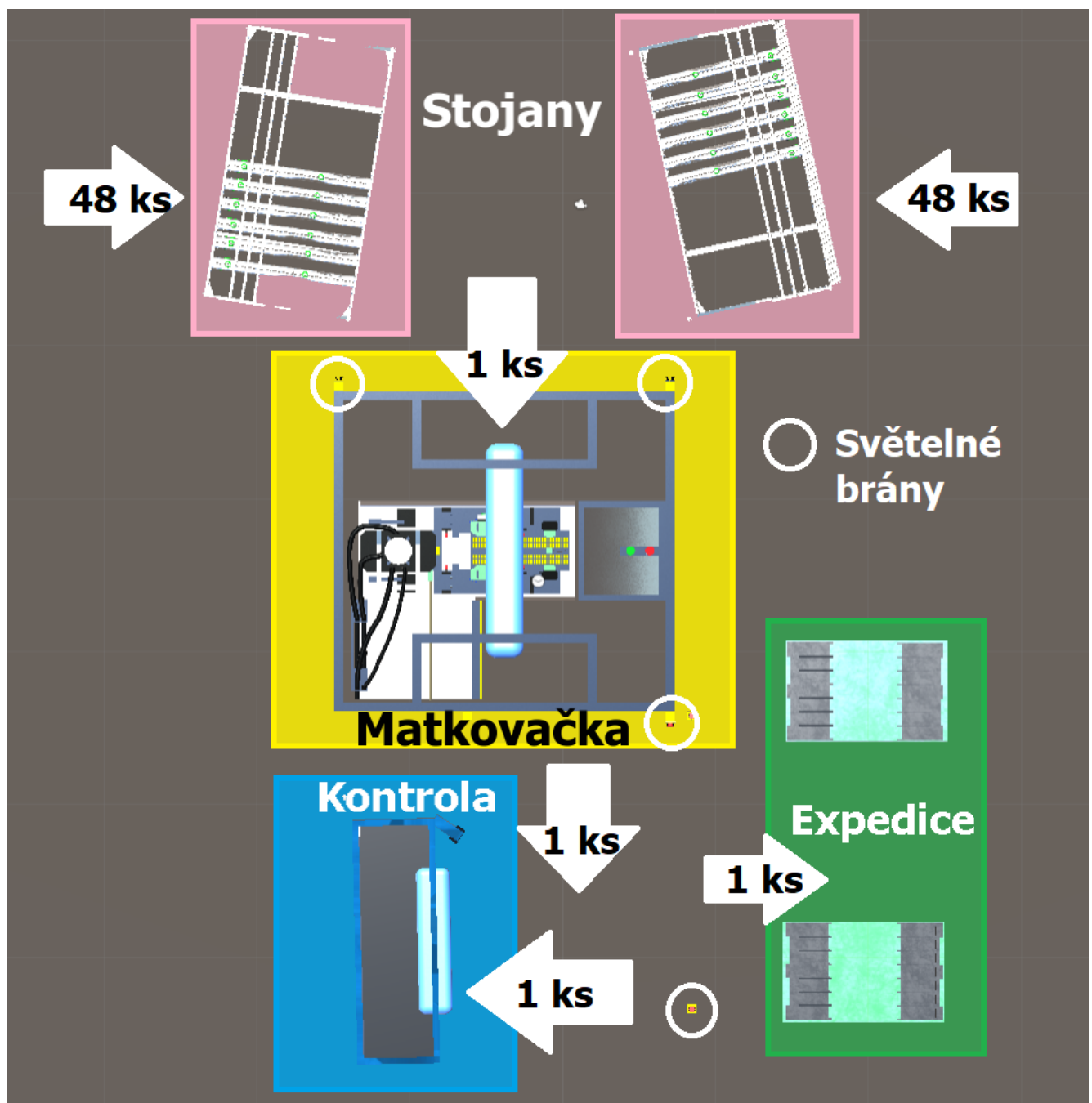

Obrázek 6 - Layout pracoviště [zdroj: autor]

Pozice jednotlivých prvků $v$ layoutu je dána podle předem nadefinovaných pozic, které jsou vyznačeny na místě. Úkolem této práce není řešit vylepšení prostorového uspořádání pracoviště. Layout je přiložen pro lepší přiblížení a orientaci pracovního místa. Z toku materiálu je vidět, že na pracoviště je přiváženo 48 kusů nosníků ve stojanech, ze kterých jsou jednotlivé díly odebírány a vkládány do lisovacího stroje. Z toho je pak tento kus odebrán, podroben kontrole a po načtení kódu a uložen do expedičních beden. 


\section{Spaghetti diagram}

Tento diagram udává, jakou měrou se pracovník pohybuje na daném pracovišti. Z diagramu je možné vyčíst, jestli pracovník nevykonává nadbytečné pohyby a nezpomaluje tak celý proces. Výsledky tohoto diagramu jsou důležité pro určení hardwaru návodky. Napomůže určit, zda je možné využít statický monitor nebo by bylo zapotřebí řešení monitorem s pojezdným stojanem.

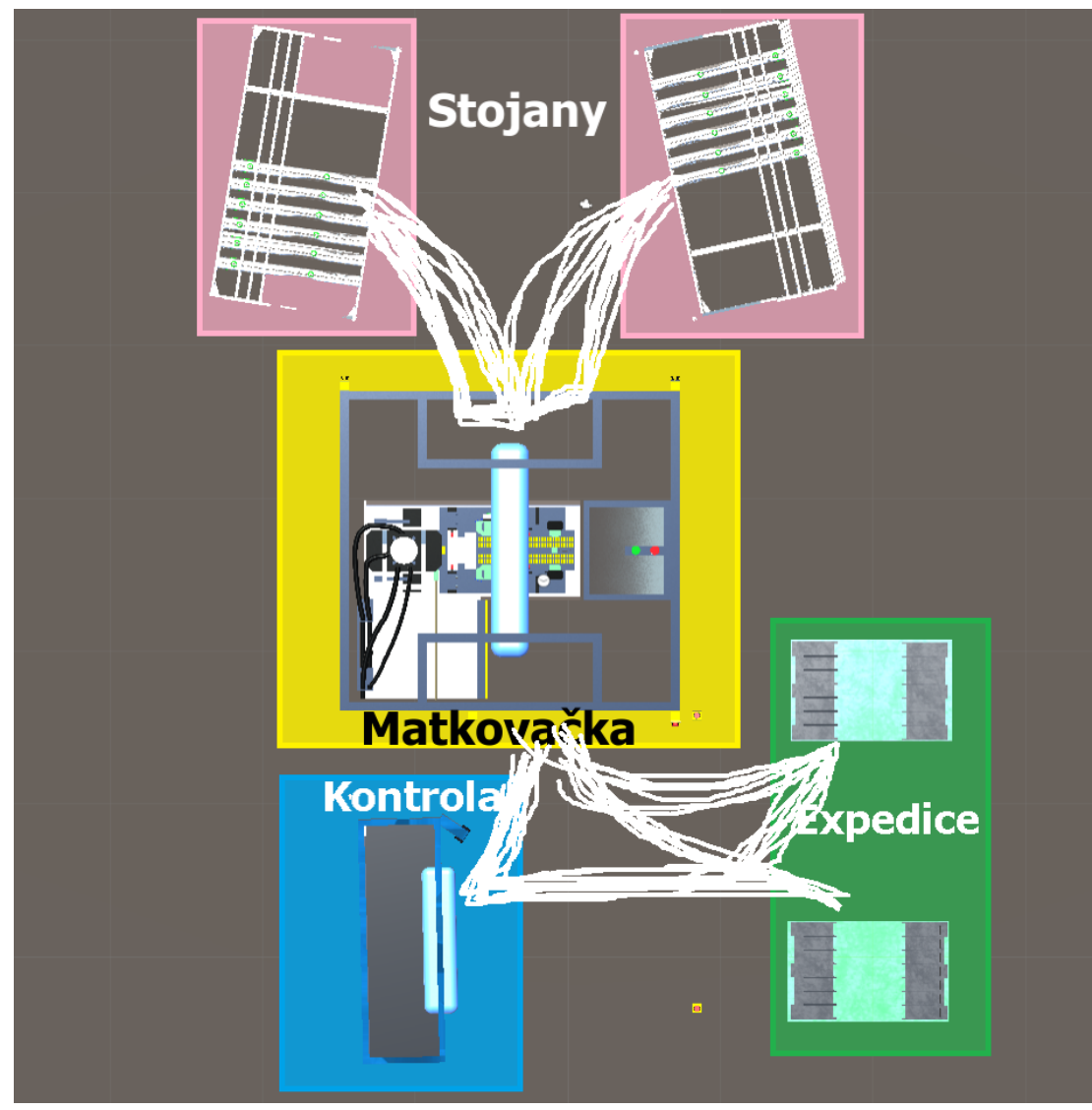

Obrázek 7-Spaghetti diagram [zdroj: autor]

Na obrázku 7 jsou bílou čarou znázorněny pohyby pracovníků obsluhujících stroj na lisování matek. $Z$ diagramu Ize vyčíst, že pracovníci vykonávají pouze nezbytný pohyb pro vykonání daného pracovního úkonu. Tento diagram společně se zorným polem (popsán níže) je jedním z nejdůležitějších faktorů ovlivňujícím umístění hardwaru pro návodku.

\section{Zorné pole}

Zorné pole na pracovišti určuje, jestli bude možné přehrávanou návodku pozorovat při vykonávání práce. Významně také ovlivní výběr hardwaru.

\section{Implementace}

Celková implementace návodek byla rozdělena na tři podkapitoly: Zpracování návodky, Propojení návodky a Hardware pro zobrazování. Jednotlivé kroky na sebe navazují a v celkovém bloku tak určují jednoznačný návod, jak 
postupovat při samotné implementaci návodky od jejího založení až po instalaci na pracovišti. V kapitolách niže autor využívá poznatků nabytých při řešení předešlých projektů.

\subsection{Zpracování návodky}

Zpracování celé návodky autor vypracoval v programu Unity 3D. Toto prostředí je velice intuitivní a pro autora známé, jelikož v něm řešil i svoji bakalářskou práci. Pro tvorbu návodky byl autorovi poskytnut program od Katedry průmyslového inženýrství a managementu.

Základem pro tvorbu samotné návodky jsou modely. $V$ předchozí kapitole bylo popsáno, že vlastní model pracoviště musel být vytvořen, a to hlavně $\mathrm{s}$ důrazem kladeným na detail provedení zejména $\mathrm{v}$ části lisovacího stroje, kde je vysoká míra rizikovosti při vkládání dílu. Hlavní komponenta, tedy stojan pro část motoru, byla poskytnuta zadavatelem. Tento model ovšem musel být upraven.

Po nastavení a vložení modelů do Unity3D bylo zapotřebí připravit scénu tak, aby odpovídala realitě. Díky prostorové analýze, ve které jsou zaznamenány veškeré rozměry pracoviště, bylo možné nastavit všechny vzdálenosti stojanů od lisovacího stroje, vzdálenost čtečky kódů, která je umístěna na pomocném stole u lisovacího stroje a vzdálenost expedičních boxů podle přesně stanovených pozic.

Dalším postupem bylo navržení vyhovujícího UI, tedy vizuální stránky celé návodky. Bylo zapotřebí zvětšit veškeré textové pole, aby je bylo možné přečíst $z$ určité vzdálenosti. Jako pozadí byl zvolen odstín bílo-šedé na kterém nejvíce vynikly všechny komponenty návodky. Zvětšení také doznala tlačítka pro př́padné ovládání kroků. Tato úprava tak změnila celý vizuální pohled na návodku.

Z procesní analýzy bylo zjištěno, že je zapotřebí vytvořit dvě samostatné návodky pro každé pracoviště zvlášt', jelikož jsou pracoviště obstarávána samostatnou obsluhou. Pracovní postup (na obou pracovištích) se skládá ze čtyř kroků. Tomu musí odpovídat i počet hlavních animovaných kroků $\checkmark$ návodce. $V$ určitých krocích je možné narazit na rizikové činnosti. Takové činnosti je zapotřebí $v$ návodce zvýraznit a poukázat na ně pomocí jednoduchých standardizovaných symbolů. Tyto symboly jednoznačně upozorní uživatele na to, že si $v$ daném kroku má dát pozor na vykonávanou práci a dbát zvýšené pozornosti. Symboly byly voleny jednoduché a specifické pro vykonávanou činnost, mimo jiné z důvodu cizojazyčných zaměstnanců. 


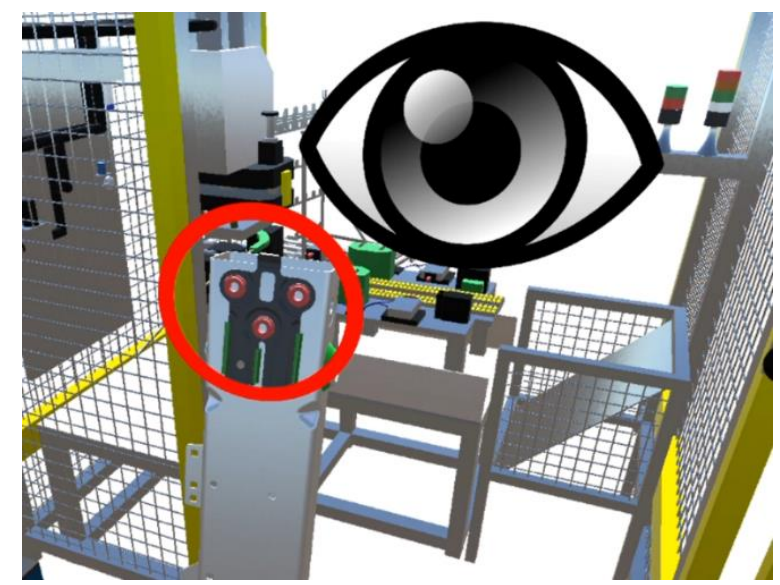

Obrázek 8 - Symbol pro ukázání rizika [zdroj: autor]

Dalším nutným prvkem vycházejícím z procesní analýzy bylo přidání číslování kroku v cyklu a jeho stručný popis. To napomáhá pracovníkovi se rychle zorientovat, $v$ jakém kroku pracovního postupu se aktuálně nachází a jaký krok následuje.

Z časových analýz obou pracovišt' bylo zjištěno, že takt obou pracovišt' je príliš nízký z toho vyplývá, že nebude možnost využívat krokovacích tlačítek. Pro nastavení návodky to ovšem znamená, že návodku nelze rozdělit na animační kroky, nýbrž pouze na jeden krok, který v sobě obsahuje jednotlivé animace. Toto opatření zajistí to, že návodka poběží v jednom kroku dokola. Důležité je ovšem nastavit časy jednotlivých animací podle reálného postupu, tak aby odpovídaly realitě. Maximální možnou odchylkou byla $\pm 1 \mathrm{~s}$.

Proto aby mohla být návodka finálně nasazena do provozu, bylo nutné ji před finální verzí konzultovat s odpovědnými zástupci firmy. Při této konzultaci byli přizvání odborníci na proces vykonávaný na pracovišti Lisování matek. Jejich odborná konzultace napomohla k odladění některých nejasností, jako například přidání znaku pro lepší znázornění vizuální kontroly, pro lepší orientaci, jaké svary se kontrolují v daném kroku, ale i např́klad pro to, kdy má pracovník použít ruku. Tedy přidání modelu ruky, naznačující reálný pohyb ruky v pracovním úkonu. 


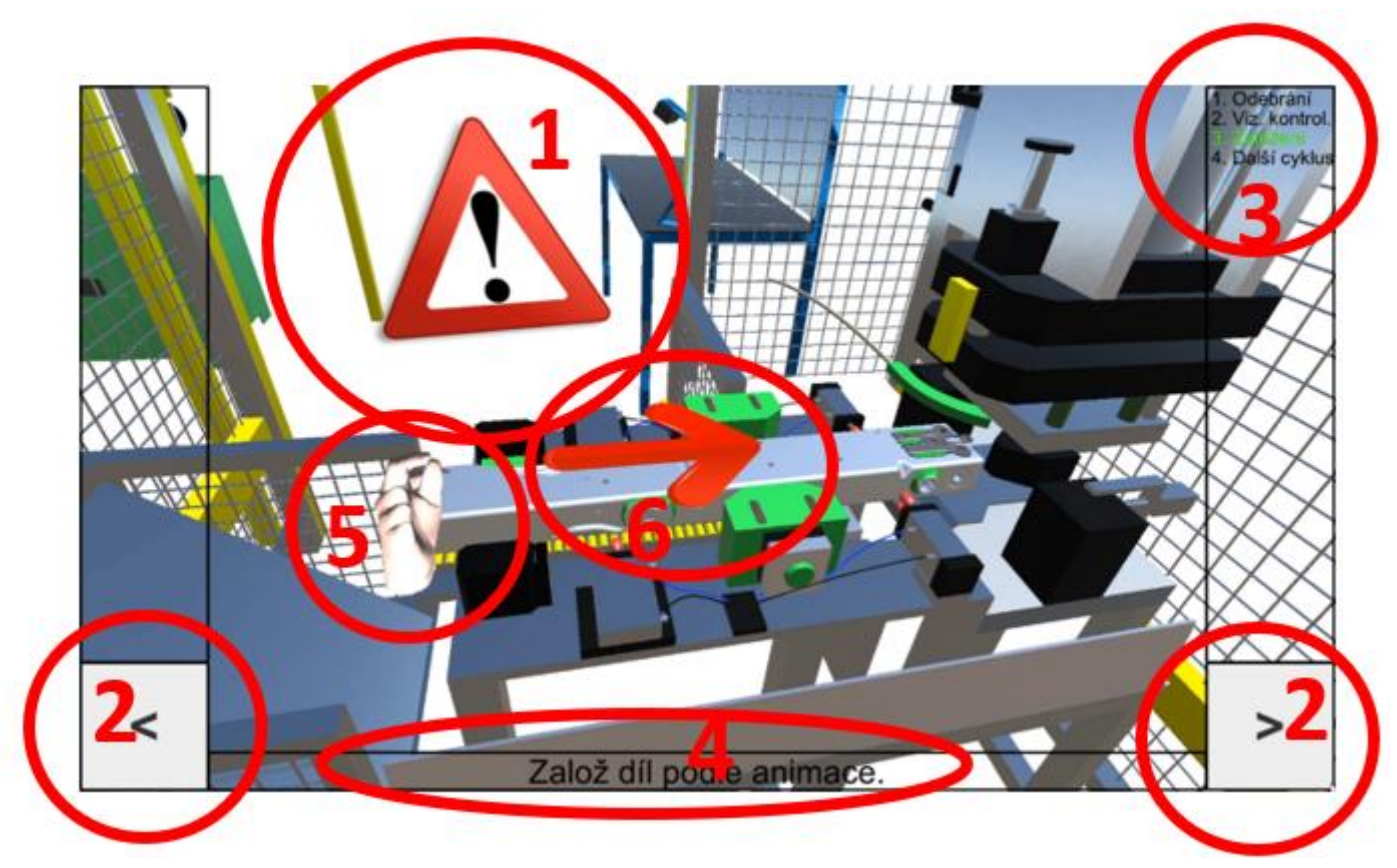

Obrázek 9 - Finální vzhled návodky [zdroj: autor]

1. Symbol pro výskyt možného rizika

2. Krokovací tlačítka, volba kroku dozadu/dopředu

3. Pořadí jednotlivých kroků v procesu

4. Dodatečné informace $k$ aktuální animaci

5. Symbol ruky napomáhající k rychlému určení prìtažení dílu

6. Symbol pro určení směru přitažení dílu

Samotná výstupní aplikace $v$ tomto kroku nebyla realizována, protože nebylo ž̌ejmé, jaký typ hardwaru bude na pracovišti použit. Tzv. Build, tedy vytvoření aplikace, může ovlivnit to, jaký typ operačního paměti bude použit a jak výkonná zařízení budou vybrána. Od toho se také odvíjí nastavení grafického stupně návodky.

\subsection{Synchronizace návodky}

Díky výsledkưm časové analýzy bylo zjištěno, že nebude možné ovládat návodku pomocí tlačítek na displeji nebo pomocí přidaného hardwarového tlačítka. Při tak nízkém taktu by to znamenalo zpomalení celého procesu a tím vedlo $\mathrm{k}$ nižší produktivitě. $Z$ toho vyplynulo, že návodku bude potřeba ovládat automaticky.

Po důkladné analýze procesu a celého pracoviště, byl navržen následující postup, jak získat signál pro automatické puštění návodky.

\section{Vstupní signály}

\section{Pracoviště: Zakládání dílů}

Pracovník na pracovišti Zakládání dílů při každém ukončení cyklu musí zmáčknout tlačítko umístěné na kleci stroje (pravá/levá strana klece podle toho, z jaké strany aktuálně odebírá díl). Toto tlačítko dá signál stroji pomocí 
programovatelného automatu (PLC), který vydá pokyn k začátku nalisování matky. Právě tento signál je určující pro zahájení animace návodky.

\section{Pracoviště: Kontrola nalisování}

Na pracovišti Kontroly nalisování pracovník nepoužívá žádné tlačítko pro spuštění dalšího cyklu nalisování. Pracovník pouze prochází skrze světelné brány, které kontrolují, zda nevchází do stroje ve špatný čas. Spouštěcím momentem $v$ tomto procesu ovšem je dokončení nalisování. To, že bylo dokončeno nalisování je jasným signálem pro spuštění návodky od začátku.

Problém nastal při pokusu o sběr dat z programovatelného automatu. Po vzájemné konzultaci s odborníky zabývající se nastavením strojů prímo v podniku, bylo jasné, že doprogramování PLC není možné, jelikož je chráněno centrálou celé společnosti. Takový zásah by mohl narušit chod celého stroje a změnit jednotlivé cykly procesu. Velkou otázkou tedy bylo, jak získat vysílaný signál z tlačítek nebo stroje. [2]

\section{Hardwarové možnosti pro sběr dat}

Pro sběr dat takového typy existuje několik zařízení. Pro tuto variantu byly vybrány tři, které jsou popsány níže a pomocí rozhodovací tabulky, která byla sestavena autorem, byla vybrána nejlepší volba.

V následujícím kroku bylo zapotřebí vybrat vhodné zařízení.

Tabulka 1 - Porovnání modulů [zdroj: autor]

\begin{tabular}{|c|c|c|c|c|}
\hline & ovládání & $\begin{array}{c}\text { galvanické } \\
\text { oddělení }\end{array}$ & $\begin{array}{c}\text { nahrazení } \\
\text { myši/klávesnice }\end{array}$ & cena \\
\hline Quido USB & USB & Ano & $\mathrm{Ne}$ & $1390 \mathrm{kč}$ \\
\hline Adam - 6051 & Ethernet & Ano & $\mathrm{Ne}$ & $4550 \mathrm{kč}$ \\
\hline $\begin{array}{c}\text { Arduino } \\
\text { Leonardo }\end{array}$ & microUSB & $\mathrm{Ne}$ & Ano & $650 \mathrm{kč}$ \\
\hline
\end{tabular}

V tabulce 1 byly porovnány klíčové vlastnosti potřebné pro realizaci.

Ovládání: ethernetové připojení přes sít'/ prripojení pomocí USB/microUSB prímo do PC

Galvanické oddělení: odděluje dvě nebo více částí obvodu, aby nebyly spojeny vodičem, ale zároveň aby byl umožněn průchod el. energie

Nahrazení myši/klávesnice: jednoduchá funkce, kdy ovladač dokáže simulovat funkce myši nebo klávesnice

Cena: cena za jeden kus.

Hlavním faktorem pro výběr modulu byla cena. Tou volbě Arduino Leonardo nemůže konkurovat a díky vlastnostem, kterými disponuje, bylo jasnou volbou. Dalším důležitým bodem bylo nahrazení myši/klávesnice. Tuto funkci splňuje Arduino Leonardo, které dokáže přeměnit signál na vstupu na fiktivní 
zmáčknutí klávesy šipky vpravo na výstupu, tedy do ovládacího PC přímo pomocí propojovacího kabelu microUSB/USB. To významně napomohlo prí rozhodování, jaký modul využít.

Protože ovšem Arduino Leonardo není vybaveno galvanickým oddělením, bylo zapotřebí takové opatření doupravit. Do spojové desky bylo zapotřebí přidat elektrický kondenzátor, keramický, uhlíkový rezistor. Tyto komponenty napomohly ke galvanickému oddělení, a tak i k bezpečnému napojení na ostrý provoz.

Celým srdcem a hlavní částí funkčnosti Arduina je kód, který bylo zapotřebí vytvořit. Ardunio je možné programovat pomocí jazyku $\mathrm{C}++$ nebo knihovnou Wiring. Tento kód se píše v prostředí nazvaném Arduino Ide, který je volně ke stažení na webových stránkách Arduina.

Byl vytvořen program (obdobným postupem jako je popsáno výše), který sleduje stav pinu na vstupu. Takovým signálem je stisknutí tlačítka, respektive dokončení nalisování. Po tomto signálu Arduino „pošle“ signál šipky doprava, což spustí krok návodky od začátku. Díky časové synchronizaci tak průběh návodky odpovídá reálnému procesu. Po testování aplikace musela být do kódu přidána ochrana proti tzv. dvojkliku. Takový problém by mohl nastat, kdyby obsluha pracoviště omylem zmáčkla signální tlačítko dvakrát za sebou. Tento problém se vyřešil pomocí príidání prodlevy po prǐjetí pinu, tzv. Delay ta byla nastavena na $1000 \mathrm{~ms}$, což „dvojklik“ bezpečně ochrání. Aby mohlo být Arduino nainstalováno prímo na pracoviště, bylo ho zapotřebí umístit do prưmyslové krabičky s DIN lištou pro prímé umístění do rozvodní skříně, která je umístěna u stroje.

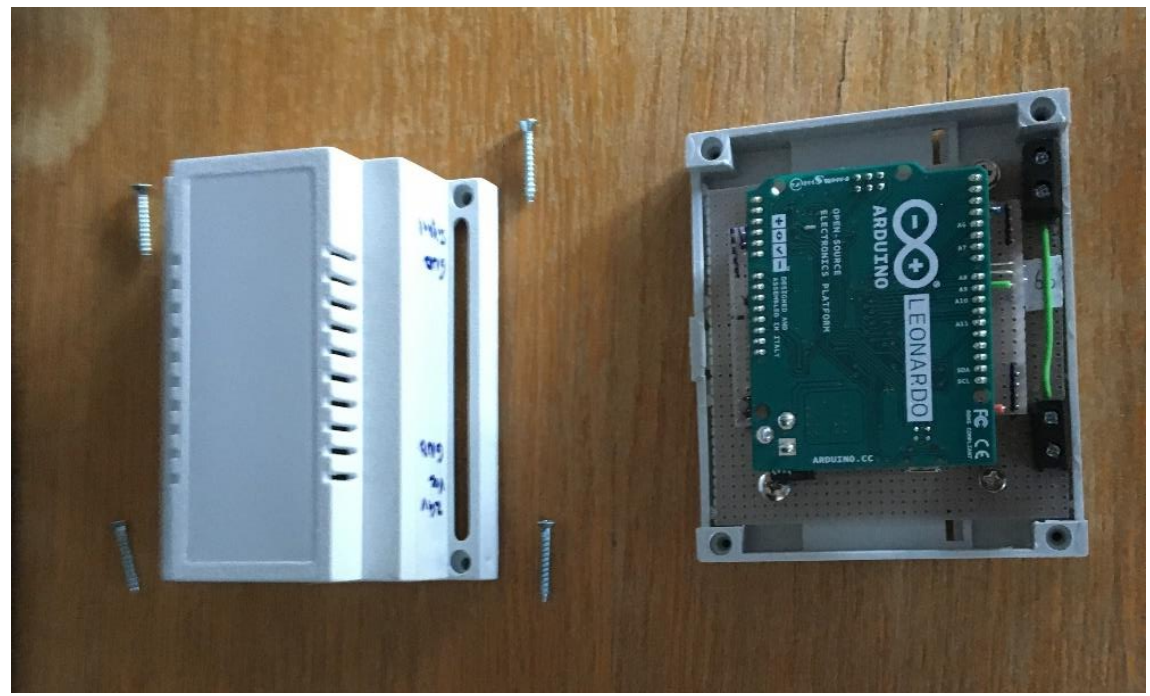

Obrázek 10 - Arduino umístěné v krabičce na lištu DIN [zdroj: autor]

\subsection{Zobrazovací zařízení}

Díky procesní a prostorové analýze bylo zjištěno, že je pracoviště rozděleno na dvě samostatné části, které jsou obsluhovány každá jedním pracovníkem. Přičemž pohled pracovníků (při hlavní činnosti) směřuje čelem $k$ sobě. $Z$ této 
analýzy tedy vyplynulo, že budou zapotřebí dva monitory, které budou oddělené a směřovat na konkrétního pracovníka.

Vstupem pro volbu správného hardwaru byla prostorová analýza. Nejdřive bylo nutné zvolit správné umístění monitorů. Východiskem pro správné umístění monitorů bylo zjištění zorného pole pracovníků.

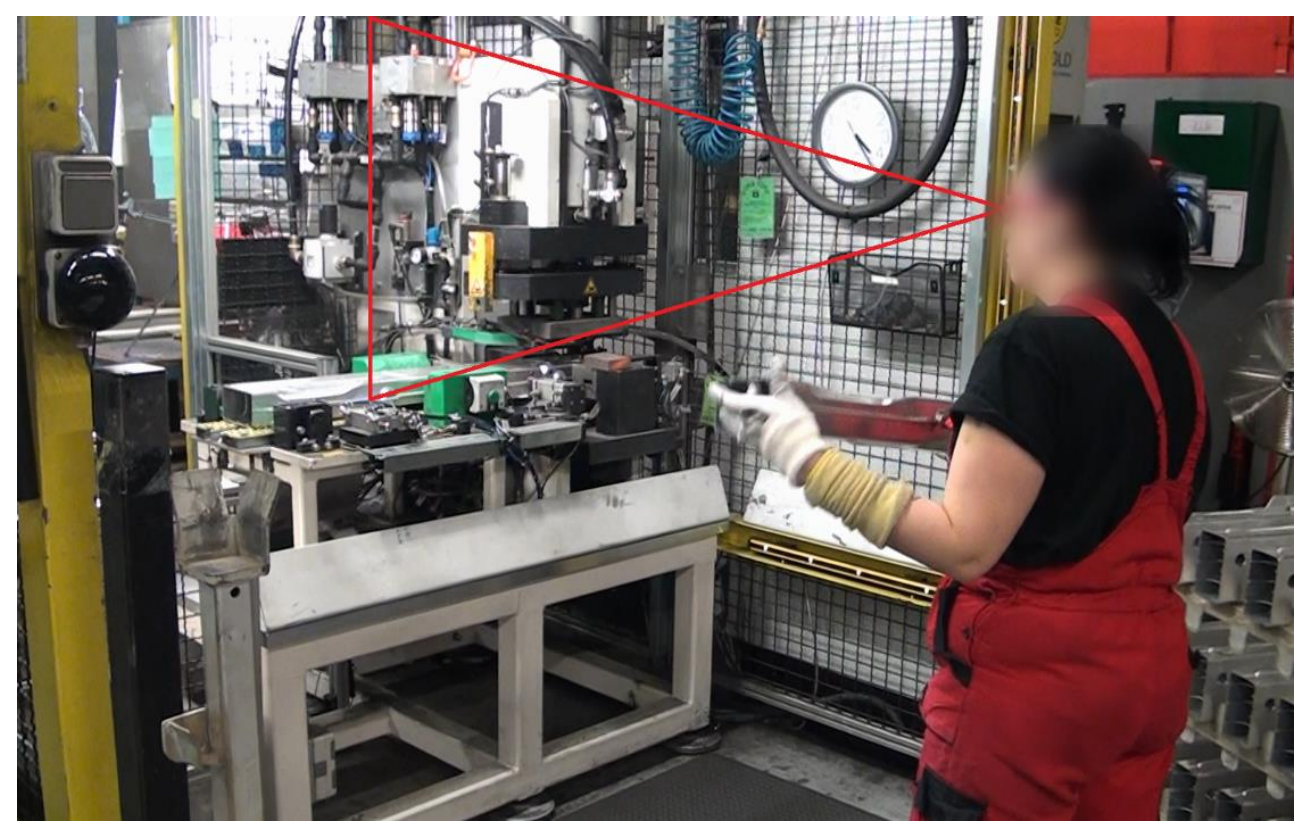

Obrázek 11 - Zorné pole pracovníka [zdroj: autor]

$\mathrm{Na}$ obrázku 11 je naznačené zorné pole pracovníka, ze kterého vyplývá umístění monitoru. Zorné pole u pracovníků na obou pracovištích je približně stejné. Díky tomu bylo možné oba monitory umístit uvnitř klece. Monitory byly umístěny zády $k$ sobě pomocí jednoduchého profilu a držáku na monitor. Tyto monitory také nijak nepřekážejí při výkonu práce. Jelikož se pracovník nepohyboval ve větší vzdálenosti než 3 metry od pracoviště, byly zvoleny monitory o velikosti 21 “. Jako monitor, který tyto požadavky splňuje byl vybrán: Monitor AOC 22P1D.

Aby mohla celá návodka fungovat a mohla komunikovat se strojem, bylo zapotřebí vybrat $\mathrm{PC}$, který všechny tyto kroky bude řídit. Nejdřive bylo nutné vyřešit umístění počítače. Varianty pro umístění počítače byly:

\section{Umístění př́mo u monitorů}

Tato volba by byla jednodušší z hlediska kabeláže - nebylo by zapotřebí delšího kabelu a připojení by tak bylo blíže k monitoru. Nevýhodou této varianty ovšem je, že je PC umístěn prímo vkleci stroje, tedy mohlo by docházet $\mathrm{k}$ přehřívání počítače. Další nespornou nevýhodou je dostupnost obsluhy. $V$ prípadě, kdy by bylo zapotřebí počítač resetovat nebo nějakým způsobem udržovat, bylo by zapotřebí přerušit proces výroby.

\section{Umístění v blízkosti stroje}

Varianta b) je sice vzdálená dále od monitorů, ale oproti variantě a) je počítač uschován ve schránce vedle klece stroje, kde je mnohem nižší teplota a tím i 
menší možnost přehřátí $P C$. Asi největší výhodou ovšem je, že je umožněna manipulace s počítačem i během chodu stroje.

Obě varianty byly konzultovány se zástupci firmy. Jako finální byla vybrána varianta b), kdy především možnost obsluhy i za chodu stroje hrála hlavní roli.

Protože bylo vybráno umístění PC ve speciální „oplechované bedně“, o rozměrech cca $40 \times 50 \times 20 \mathrm{~cm}$, bylo zapotřebí vybrat typ počítače, který by bylo možné uložit do takto definovaného prostoru. Jako finální byl vybrán: DELL OptiPlex MFF 3070. Tento počítač splňuje jako grafické, procesorové, tak i rozměrové požadavky. Po vybrání typu PC bylo možné vytvořit samotný typ .exe souboru. Aplikace tedy byla vytvořena pro 64bitový operační systém.

Posledním požadavkem byl typ propojení PC s monitorem a Arduinem. Pro propojení PC a monitoru byl vybrán standardní kabel HDMl o délce 5metrů. Pro propojení Arduina s PC byl vybrán kabel s koncovkami USB $(\mathrm{PC}) /$ microUSB (Arduino).

\section{Závěr}

Po vybrání vhodného hardwaru, bylo zapotřebí veškeré vybavení umístit prímo na pracoviště. Samotná instalace na určená místa probíhala za dohledu odpovědných osob. Arduino bylo pomocí DIN lišty umístěno do rozvaděčové skříně a propojeno s PC pomocí kabelu USB. Mini počítač Dell byl umístěn do připraveného boxu vedle klece stroje. Monitory byly umístěné prímo v kleci stroje a každý z monitorů byl propojen do PC pomocí HDMI kabelu.

Samotné aplikace návodky mohly být nahrány do PC. Před samotným spuštěním proběhlo testování návodky, ve kterém se vyskytlo několik problémů.

Obě návodky se zobrazovaly na jednom monitoru. To bylo způsobeno tím, že PC nerozpoznával druhý monitor. Tento problém se povedlo vyřešit jednoduchým řešením, a to spuštěním aplikace pomocí vlastního dávkového soubor (typu .bat). Do tohoto souboru je zapotřebí zapsat následující príḱkazy:

Start „název exe souboru“.exe -adapter1

Exit

Tato jednoduchá úprava spustí okamžitě návodku na druhé monitoru.

Další problém nastal u návodky Kontroly nalisování. Problém byl, že stroj nespínal návodku $v$ požadovaném čase. To bylo zapríčiněno pouze volbou špatné proměnné, kterou byla proměnná „status“ což je ovšem interní Arduino funkce. Tato chyba byla vyřešena jednoduchou změnou názvu proměnné.

Po odstranění těchto drobných chyb byla návodka připravena na ostrý provoz.

Na obrázcích níže je zachycen výsledný stav celého pracoviště osazeného monitory a funkčními návodkami. Na Obr. 12 je zobrazeno, jak bylo Arduino i $s$ krabičkou pro uchycení na DIN liště umístěno v rozvodné skříni. 


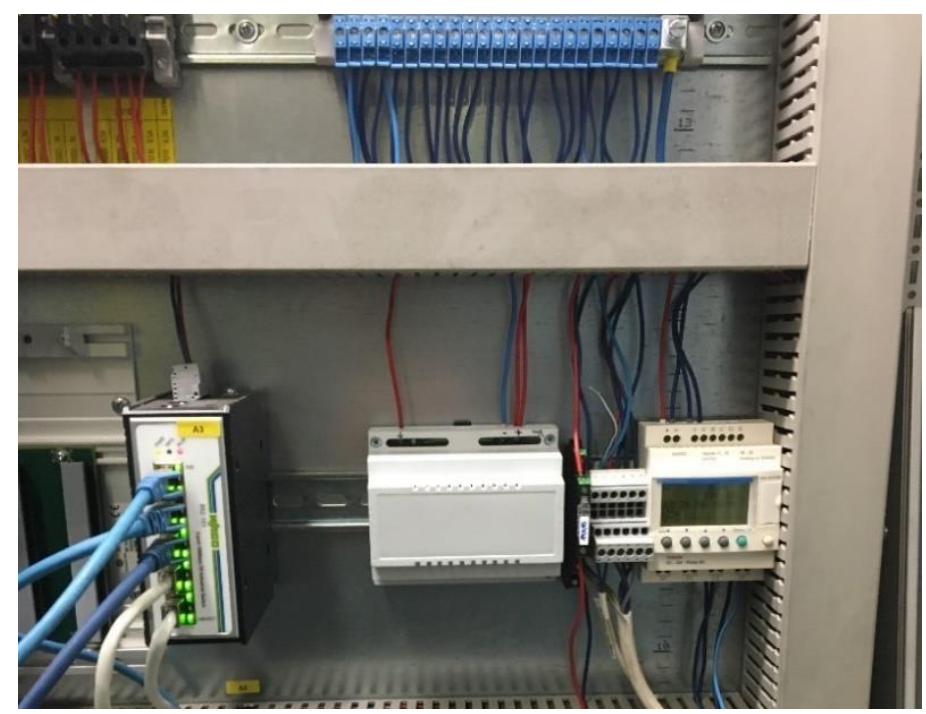

Obrázek 12 - Arduino v rozvodné skříni [zdroj: autor]

Na obrázku 13 je znázorněné pracoviště osazené monitorem promítající návodku pro dané pracoviště.

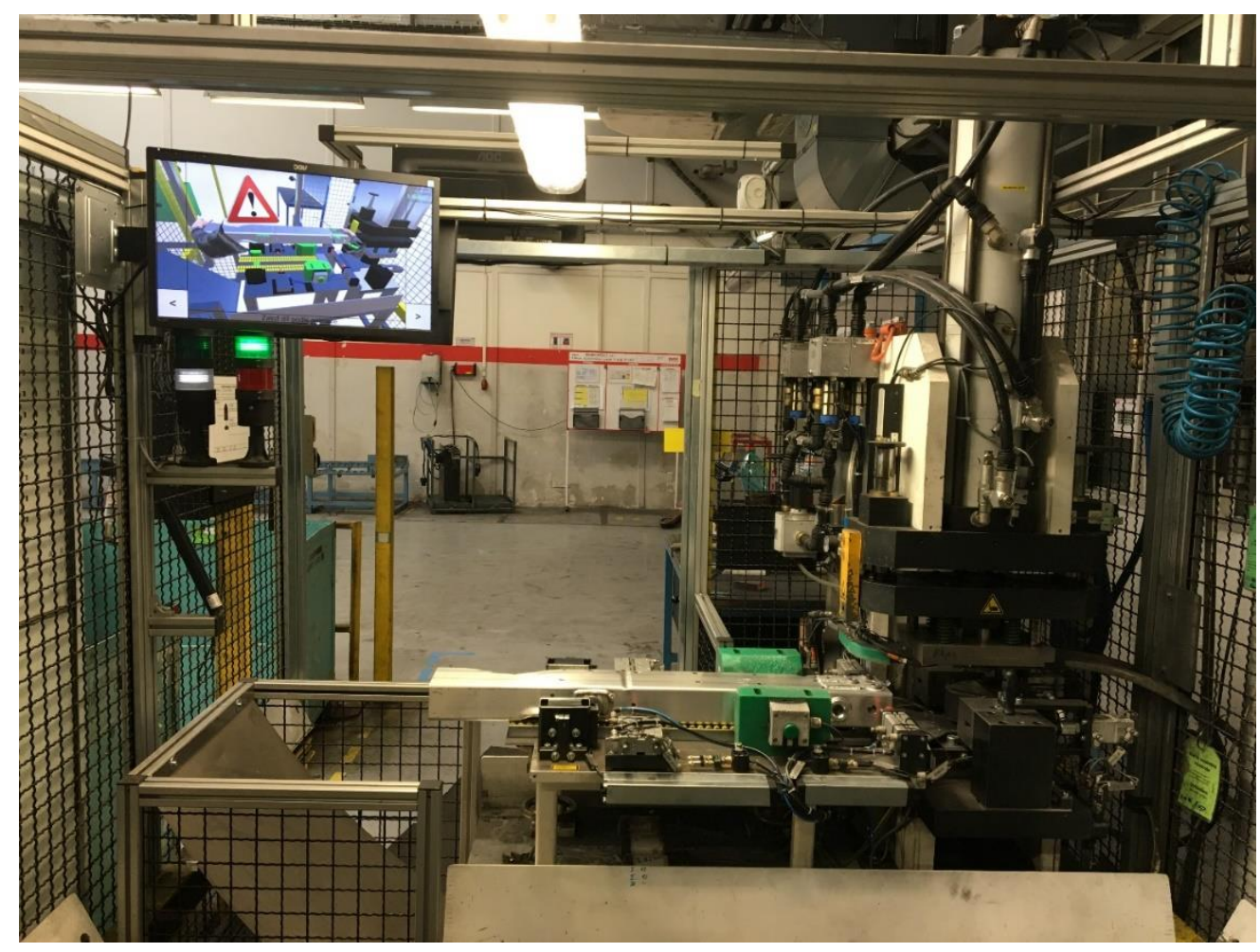

Obrázek 13 - Monitor s návodkou na pracovišti [zdroj: autor]

\section{Poděkování}

Tento článek byl vytvořen za podpory interního grantu Západočeské univerzity číslo projektu je SGS-2018-031 s názvem Optimalizace parametrů udržitelného výrobního systému. 


\section{Použitá literatura}

[1] NOVIKOV, K. Zefektivnění provádění výrobních procesů v rámci technické prípravy výroby. Plzeň, 2019. Teze k disertační práci. ZČU v Plzni.

[2] FOXON s.r.o. \& Blažek J. Kurzy programování PLC Siemens Simatic. [Online] 2013 [cit. 20.11.2019]. Dostupné z: https://foxon.cz/blog/kurzyprogramovani/kurzy-programovani-simatic-s7-300/182-kurz-programovaniplc-siemens-simatic-s7-300-dil-1\#tri

[3] HOŘEJŠí, P. Využití virtuální a rozšiřené realit v průmyslu. Plzeň, 2019. Habilitační práce. ZČU v PIzni.

[4] LINOWES, J. Unity Virtual Reality Projects. Birmingham: Packt Publishing, 2018. ISBN 978-1-78847-880-9.

[5] Forbes Technology Council. 10 Ways VR Will Change Life In The Near Future. [Online] 2018 [cit. 25.10.2019]. Dostupné z: https://www.forbes.com/sites/forbestechcouncil/2018/08/31/10-ways-vr-willchange-life-in-the-near-future/\#3f5f6da63d94

[6] New Virtual Reality Application: Supermarket VR. [Online] 2017 [cit. 2.12.2019]. Dostupné z: https://horizonstreetview.wordpress.com/2017/08/02/new-virtual-realityapplication-supermarket-vr/.

[7] Comfor. [Online] COMFOR STORE a.s., 2018. [cit. 5.4.2020]. Dostupné z: https://www.comfor.cz/periferie/monitory/22-led-aoc-22p1d-fhd-hdmi-dvi-reppiv. 